\title{
Effective Academic Advisory Committee Relationships
}

Donna M. Schaeffer, Marymount University, USA

Donald (Nick) Rouse, Marymount University, USA

\begin{abstract}
Recently, accrediting bodies are placing great responsibility for accountability on universities and academic schools, departments, and programs. The goal of the increased accountability is improved quality of teaching and learning. In this paper, we describe several levels of accountability for quality teaching and learning in a small, private, liberal arts college. We describe the role the University's Board of Trustees. Moving to the School of Business Administration, we explain several activities the Board of Visitors facilitate and participate in. Then, we localize to the Department of Information Systems and Management Science, which has had an advisory committee comprised of award-winning Chief Information Officers and Chief Technology Officers since 2009-2010. Finally, we describe efforts involved in building an advisory committee for a new academic program within the department, the Bachelor's in Health Information Management (HIM). This examination provides insights and examples for others who are seeking to establish or re-invigorate their relationships with advisors. It is interesting in that some cases the advisory committee is mandated by law, e.g., the University of Board of Trustees, others are voluntary, e.g., the School's Board of Visitors and the department's advisory committee, and still others may be prescribed and required by accrediting bodies within particular fields, e.g., the Health Information Management (HIM) program.
\end{abstract}

Keywords: Advisory Committees; Academic Programs; Committee Relationships

\section{INTRODUCTION}

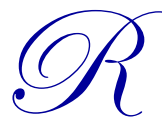

Tecently, accrediting bodies are placing great responsibility for accountability on universities and academic schools, departments, and programs. Merriam-Webster (2013) defines accountability as "an obligation or willingness to accept responsibility for one's actions." Burke (2005) identifies six facets of accountability for higher education: 1) using their powers properly, 2) achieving the organization's mission or priorities, 3) reporting on performance, 4) using resources efficiently and effectively, 5) ensuring the quality of the programs and services produced, and 6) serving public needs.

\section{Quality Assurance}

At least one of these factors - attention to quality - is a world-wide phenomenon. The Organization for Economic Co-operation and Development (OECD) launched its Assessment of Higher Education Learning Outcomes project in 2006. It focuses on interactions between student and faculty, career expectations, completion rates, and graduates' and success in finding a job (OECD, 2010). Higher education policy issues have risen to the top of the agenda in the G8 countries, other industrialized nations, and developing countries.

Interest in accountability has reached the "consumer" level, as well. Students, parents, and employers are demanding some kind of quality assurance. Universities are no longer working in isolation, but need to be perceived as interactive players with industry, community, and government (OECD, 2010). Responsiveness to market needs is particularly essential when new disciplines emerge, as was clear in the case of computer science in Ireland (Sands, 2005). Universities partnered with industry to build research centers and develop curricula, and now major companies including IBM, Intel, and Lucent have facilities in Ireland. 
Attbach, et al. (2010) notes that one way to be responsive to trends in industry is to have externally active academic staff. An emerging area is student participation in work-study programs or internships. While one externally active faculty member may be aware of external needs and may even reflect such knowledge in their individual course, is it essential to have processes in place to ensure timeliness and relevance of program offerings (Attbach, 2012). Individual students may find work-study jobs or internships, but efforts must be systemized. An effective process may be to effectively use an advisory committee. The effective use of advisory committees can turn accountability into a proactive, constructive decision making process (Reeves, 2004).

\section{FORMS OF ADVISORY COMMITTEES}

Some advisory committees are mandated by law or required by accrediting bodies; others are voluntary. In higher education, advisory committees may take the form of a university - wide Board of Trustees and advisory committees for individual academic units, such as schools or colleges, departments, or programs. Advisory committees are typically long-term in nature; however, they may sometimes be formed for short-term or ad hoc issues.

\section{University Board of Trustees}

Educational institutions in the United States are required by law to have Boards of Trustees (sometimes called Boards of Directors). Boards are responsibility for the well-being of the institution, including academic and administrative functions, mostly through establishing or approving policies and ensuring the policies are followed. Taylor (1987) describes the relationship as paradoxical, since in order for the institution to function properly, the relationship between the Board and president should be harmonious and based on mutual support and trust, yet the board has the final authority over institutional policies and is authorized to hire and dismiss the president.

Typically, Boards are externally oriented but in their internal orientation, they serve as advisors to the Presidents and other leaders. Faculty leaders and other administrators may be called upon to educate, inform, and motivate the board. Faculty leaders and other administrators often communicate with the Board, have input into their agendas, and provide background information. In some cases, the faculty influences the selection and development of trustees (Taylor, 1987). When there is an effective relationship, faculty will see Board members as resources and allies and use the trustees' talents (Taylor, 1987).

In American higher education, the general public typically becomes aware of Boards during times of crisis, such as recent sports scandals or financial hard times. In some cases, members of Boards may be called upon to take operational roles. Two quotes from University of Pennsylvania board member John P. Surma illustrate the long-term interests a Board of Trustees oversees, their sense of responsibility for things that happen on a day-to-day basis, and their independence. These statements were made following the Board's decision to fire coach Joe Paterno, school president Graham Spanier, assistant coach Jerry Sandusky, and athletic director Tim Curley after their roles in covering up the incidents or failing to notify authorities of sexual assaults of underage males that had taken place by Sandusky over a number of years on or near the University premises.

- In our view, things had reached a point where we had to make a change for the best long-term interest of Penn State (Cooper, 2011).

- We're not going to drink the Kool-Aid. This is what we need to do (Van Natta, 2012).

\section{Board Members}

Cunningham (1985) identified important functions: strengthen the program(s), improve the institution's management, review and evaluate the institution's mission, programs, and services, recruit personnel, raise funds, promote public relations, and improve the institution's relationships with other organizations. These functions, especially promoting public relations and improving the institution's relationships with other organizations illustrate that when properly configured, an advisory committee provides a bridge to the external public (Thompson, 1984). 


\section{Advisory Committees for Specific Academic Units or Activities}

Teitel (1994) defines an advisory committee as a group of volunteers that meets regularly on a long-term basis to provide advice and/or support to an institution or one of its subunits. The Minnesota Office of the Chancellor gets more specific, calling for “... employers and employees who advise educators on the design, development, implementation, evaluation, maintenance, and revision of technical/occupational education programs. Each advisory committee is made up of individuals with experience and expertise in the occupational field that the program serves." An advisory committee differs from a Board of Trustees in that it does not have fiduciary or legal authority for the organization or program, nor do advisory committees have decision making authority; their function is to provide assistance, to advise, and to make recommendations (Caparosa, 1984).

The major functions of advisory committees include those around assessment and counsel, assistance, promotion and advocacy. At some institutions, advisory committees assess each area of the program and offer suggestions on ways to improve that area. Alumni or the corporations represented by members of the advisory committee may provide scholarships or operating funds as a result of their involvement in the school's governance (Hawawini, 2005).

In some cases, advisory committees promote the programs in the community. Promotion and advocacy can take forms such as communicating with legislators, arranging publicity, presenting programs to civic groups, and authoring newspaper articles. Bringle and Hatcher (1996) note that it is important to involve faculty and students in advisory committees for the specific activity of implementing a service learning program, and this lesson may generalizable to other activities, such as school or program advisory committees.

\section{CASE STUDY: MARYMOUNT UNIVERSITY}

Marymount University was founded in 1950 by the Religious of the Sacred Heart of Mary (RSHM). It is an independent, coeducational Catholic university offering bachelor's, master's, and doctoral degrees in a wide range of disciplines. Marymount University is located in Arlington, VA, just a few miles and minutes from Washington, DC. In 2013 , the University enrolled nearly 3,700 students, representing approximately 40 states and 70 countries.

The University's mission statement is:

Marymount University is an independent Catholic university that emphasizes academic excellence at the undergraduate and graduate levels. Committed to the liberal arts tradition, the University combines a foundation in the arts and sciences with career preparation and opportunities for personal and professional development. Marymount is a student-centered learning community that values diversity and focuses on the education of the whole person, promoting the intellectual, spiritual, and moral growth of each individual. Scholarship, leadership, service, and ethics are hallmarks of a Marymount education.

The University's values statement is:

Marymount University will be known as a comprehensive Catholic university and the institution of choice for students, faculty, and staff. Marymount will distinguish itself through a culture of engagement that fosters intellectual curiosity, service to others, and a global perspective.

The Religious of the Sacred Heart of Mary is an international congregation of Catholic women religious. The order has a presence in 13 countries in diverse ministries. Since 1907, the RSHM has operated school and colleges in the United States and Europe. As of 2013, there are 19 educational institutions in eight countries. mission is:

Since its founding in the 1800 s, the RSHM tenets have included globalization, inclusivity, and justice. Its

The challenge of the gospel and the spirit of faith and zeal which marked our founders, and our founding sisters, urges to respond to the needs of our time and to work with others in action for evangelical justice. At the same time 
we place ourselves and our resources at the service of those who are most in need of justice, especially women and children, enabling the powerless, the deprived, the marginalized, the voiceless to work effectively for their own development and liberation.

\section{Board of Trustees}

The University Board of Trustees has 27 members, five of whom are members of the Religious of the Sacred Heart of Mary, the order that founded the University. The Board meets quarterly. Faculty serve on Board Committees, e.g., Building and Grounds and Development. Traditionally, the Board has approved the University budget and holds the final authority on hiring decisions. In more recent years, the Board has become heavily involved in developing the University's strategic plan.

During the 2012 - 2013 academic year, Marymount University's Board of Trustees was chaired by Joseph Maurelli, former chairman, president, and CEO of Techmatics, Inc. Mr. Maurelli has been Trustee since 2007 and formerly served as Chair of the School of Business Board of Visitors. His participation shows the linkages that can exist between advisory committees at various levels. He also exemplifies the long-term vision of the Board of Trustees when he said, shortly after being elected Chairman "We're going to try to push this university to try to take the next step. Make it a go-to place for northern Virginia" (Arlington Mercury, 2012).

\section{School of Business Administration Board of Visitors}

Marymount University School of Business Administration offers diverse programs at the undergraduate and graduate levels. There is the Bachelor of Business Administration, Master of Business Administration, and the Master of Science in Management programs (accredited by the Association of Collegiate Business Schools and Programs - ACBSP); Bachelor of Arts in Economics in Society, and Master of Arts in Human Resource Management; the Master of Science in Health Care Management program (accredited by the Commission on Accreditation of Healthcare Management Education - CAHME); the M.A. in Legal Administration, the B.A. in Paralegal Studies, and the undergraduate and graduate paralegal certificate programs (approved by the American Bar Association -- ABA); the Bachelor of Science of Information Technology, Master of Science in Information Technology, and the Bachelor of Science in Health Information Management (HIM) . Additionally, there are specializations, minors, certificates, and dual degree programs.

The Marymount University Factbook 2012 - 2013 reports that in Fall, 2012, the School of Business Administration enrolled 618 undergraduate students and 397 graduate students. There are 32 full time faculty members. The School of Business Administration Board of Visitors advises the School on business and industry needs to ensure that programs are on the cutting edge. There are 25 members representing information technology, management, and human resources to catering, news media, commercial real estate, construction, and the law. The Board of Visitors meets on a quarterly basis. At the meetings, Program Directors, Department Chairs, and faculty make presentations. Throughout the school year, members of the Board of Visitors serve as Distinguished Speakers in the Deans' Lecture Series.

\section{Dean James Ryerson said:}

These business leaders, many of them alumni, have the ultimate sense of what students need to be successful in the marketplace. They regularly emphasize the importance of key skills like thinking critically, writing, and presenting, in addition to content-specific knowledge. We take their advice seriously and have modified programs based on their feedback. We continually re-evaluate courses and programs to ensure that our students are well-rounded and have the wide range of knowledge and skills that are so necessary to organizations and to personal success.

In addition to advice, the Board of Visitors provides funding for special initiatives. For example, when students in the School formed a partnership with a Kenyan Maasai village, the students developed a sustainable business plan and marketing program for the crafts the villagers make. Students in several classes are involved in the project, including marketing, IT, and advertising. Students raised the funds and purchased the initial stock of crafts. They received additional support from the Board of Visitors. The profit is split between sustaining the business and the village. 


\section{Department of Information Technology and Management Science}

During the Fall semester of 2012, the Department of Information Technology and Management Science served 130 undergraduate and 72 graduate students (Marymount University, 2012). There are eight full-time faculty members. The department's Advisory Committee was formed in 2007. It comprises of six members from the Information Systems field, one member representing Management Science, one administrator from a local community college, the Director of the School of Business Administration Internship Program, and three alumni. The members from the information systems profession are all award-winning C-level executives. They were selected from local companies or government organizations that are listed on either the ComputerWorld Best Places to Work, Fortune Best Places to Work, and Washington Business Weekly Best Places to Work. They hold such titles as Chief Information Officer, Chief Technology Officer, or Chief Security Officer. They represent the Bureau of the Census, Long and Foster Real Estate Company, County of Arlington, Sirus/XM, and IBM.

When it was formed we established a Charter which detailed the responsibilities of committee members. These responsibilities include attending two meetings each year, advising on departmental decision making regarding curriculum and admissions standards, providing feedback on Program Reviews, offering internships and job opportunities for students and alumni, inviting classes for tours of employer facilities, and discussing current events and trends in the field.

The Charter also detailed committee responsibilities and logistics. Committee members typically serve for three years. At the end of three years, we ask them to recommend a replacement, either from their organization or their professional colleagues. It is important for us that the members rotate on a staggered basis so that there is continuity and change. The members elect a Chair of the Advisory Committee, who serves for one term which may be renewed.

When a new member comes on to the Advisory Committee, they receive background on the University, its mission statement and value statement, an organizational chart of the University, School and Department, a list of programs offered by the department and our admission policies, detailed Curriculum, a tour of our classrooms and lab facilities. Throughout the academic year and especially before meeting, we provide other information as needed or requested.

For the Department of Information Technology and Management, members of the Advisory Committee have made specific recommendations regarding curriculum and provided input to the Program Review for the Bachelor of Science in Information Technology program. The members of the Advisory Committee also help secure internships for students and placements for graduates and alumni. They also serve as mentors.

\section{Health Information Management Program Advisory Committee}

Health Information Management (HIM) professionals serve patients and the medical community by managing, analyzing, and utilizing health information (Johns, 2006). This program is growing in popularity as the need for health care professionals grows. The Bureau of Labor Statistics cites health information technology as one of the 20 fastest growing occupations in the United States, with a 21\% growth rate between 2010 and 2020, faster than the average for all occupations (United States Department of Labor, 2012). US News and World Report ranked the field fourth on its list of college majors with a future (Gearon, 2012).

Some drivers of the HIM curriculum include the laws that govern the exchange of health information, especially around the areas of privacy and security; a major change in the World Health Organization's International Classification of Diseases (ICD), from ICD-9 to ICD-10; and a movement to electronic health records (EHR) and the application of the standard of meaningful use to promote transition to EHRs.

An effective health information management (HIM) program must have a community focus, a desire to continually revise the curriculum, an existing technology community, an existing healthcare community, and the desire to leverage regional healthcare needs (Hackbarth \& Cole, 2012). One of the first things any new HIM program director has to do is establish an advisory committee. The advisory committee serves to provide input into what the business community, local community and health facilities are looking for in the graduates. 
At Marymount, we sought to establish an advisory committee whose members represented a good cross section of the local community and who were at various level of the HIM profession. To find members, we turned to colleagues in the allied health and professional organizations such Health Information Management Systems (HIMSS) and American Health Information Management Association (AHIMA). Our members include a Public Health Analyst from the United States Department of Health and Human Services, the Executive in Residence at the HIMSS Foundation Institute for e-Health Policy, the Operations Manager from Holy Cross Hospital, a consultant who specializes in RxNorm and Unified Medical Language System (UMLS) projects sponsored by the National Library of Medicine, and a student.

The selection criteria for the student member included tangible and non-tangible characteristics. We looked to grade point average and classroom performance, as well as their networking tendencies. The student who was selected is one of the top performers in the classroom, is sociable with other students, and regularly attends professional organization meetings in the Washington DC metro area.

\section{CONCLUSION}

The literature and our experiences indicate that the long-term successful partnership between an Advisory Committee and an academic unit requires that the members of the advisory committee see results. At the Department Advisory Committee, we report back that their recommendations were acted upon.

It is important to find members who are willing to commit. In order for the committee to gel, the same individuals must be available to meet regularly on a long term basis. Faculty and administrators need to give thought to the size of the advisory committee. Committees with more than 12 members can become unmanageable, and those with five or fewer members may lack diversity and provide a narrower outlook. Establishing goals and objectives helps the committee become sustainable beyond individual members. Finally, it is critical to involve support staff. Our administrative assistants secure the location and food, issue invitations, take and distribute minutes.

We find that the establishment and active involvement of Advisory Committees adds credibility to our programs. The professionals' input ensures our programs are on the cutting edge. In the cases where the Advisory Committee is required by accrediting agencies, having one meets that criterion. Finally, and quite possibly most importantly, the advisory committee ensures the institution, department or program does not operate in vacuum.

\section{AUTHOR INFORMATION}

Donna Schaeffer, Ph.D. received her PhD in the Management Information Systems from the Claremont Graduate University. She has taught at universities in the United States and abroad. She has won awards for outstanding teaching three times in her academic career. Dr. Schaeffer has published over 50 articles and book chapters. She is a member of, and has held leadership positions, in computing and civic associations including American Association for the Advancement of Science, Decision Sciences Institute, Institute of Electrical and Electronic Engineers, John Dewey Society, National Disaster Preparedness Coalition, World Affairs Council, Women's High Tech Coalition, and Women in International Security. Donna M. Schaeffer, Ph.D., Associate Professor, Marymount University, School of Business Administration, 2807 North Glebe Road, Arlington, VA 22207 USA. E-mail: Donna.schaeffer@marymount.edu (Corresponding author)

Donald (Nick) Rouse, Ph.D., Assistant Professor, Marymount University, School of Business Administration, 2807 North Glebe Road, Arlington, VA 22207 USA. E-mail: drouse@ marymount.edu

\section{REFERENCES}

1. Arlington Mercury. (2012, March 26). Marymount's new board chair wants MU to be a "go to" school. Retrieved from http://arlingtonmercury.org/countywide/marymount\%27s-board-chair-wants-mu-to-be-a$\% 22$ go-to\%22-school/ 
2. Bailey, A. R., Chow, C. W., \& Haddad, K. M. (1999). Continuous improvement in business education: Insights from the for-profit sector and business school deans. Journal of Education for Business, 74(3), 165-180.

3. Bringle, R. G., \& Hatcher, J. A. (1996). Implementing service learning in higher education. The Journal of Higher Education, 221-239.

4. Bureau of Labor Statistics, U.S. Department of Labor (2012). Occupational outlook handbook, 2012-13 Edition. Medical Records and Health Information Technicians. Retrieved from http://www.bls.gov/ooh/healthcare/medical-records-and-health-information-technicians.htm

5. Burke, J. C. (2005). The many faces of accountability. Achieving accountability in higher education: Balancing public, academic, and market demands, 1-24.

6. Cooper, A, (2011, 09 November). Keeping them honest. Anderson Cooper 360. CNN. Retrieved from http://transcripts.cnn.com/TRANSCRIPTS/1111/09/acd.02.html

7. Gearon, C. (2012, September 12). Discover nine new college majors with a future. US News and World Report. Retreived from http://www.usnews.com/education/best-colleges/articles/2012/09/12/discover-9new-college-majors-with-a-future?page=2

8. Hackbarth, G., Cata T., \& Cole, L. (2012). Developing a capstone course within a health informatics program. Perspectives in Health Information Management, (Summer 2012), 1-21.

9. Hawawini, G. (2005). The future of business schools. Journal of Management Development, 24(9), 770782.

10. Johns, M. L. (2006). Heath information management technology: An applied approach. (2 $2^{\text {nd }}$ ed.). Chicago: AHIMA Minnesota Office of the Chancellor. Program advisory committees: A handbook for faculty in career and technical programs. Retrieved from http://vfc6.project.mnscu.edu/index.asp?Type=B_BASIC\&SEC=\%7B3BA72DEF-2CE5-4AD7-9FF72B9356B02FDB\%7D

11. Organisation for Economic Co-operation and Development. (2010). Assessment of higher education learning outcomes (AH- ELO). Available from: http://www.oecd.org/

12. Reeves, D. B. (2004). Accountability for learning: How teachers and school leaders can take charge. Association for Supervision and Curriculum Development.

13. Taylor, B. E. (1987) Working effectively with trustees: Building a cooperative campus leadership. ASHEERIC Higher Education Report No. 2, 1987. Publications Department, ASHE-ERIC Higher Education Reports, The George Washington University, One Dupont Circle, Suite 630, Washington, DC 20036-1183.

14. Teitel, L. (1994). The advisory committee advantage. Creating an effective strategy for programmatic improvement. ASHE-ERIC Higher Education Report No. 1. Washington, DC: Association for the Study of Higher Education.

15. Van Natta, D. (2012, 16 April). Fight on State: In wake of scandal, power struggle spread from Penn State campus to state capital. ESPN The Magazine. Retrieved from http://espn.go.com/espn/otl/story/_id/7770996/in-wake-joe-paterno-death-sandusky-sex-abuse-scandalpower-struggle-spread-penn-state-state-capital 


\section{NOTES}

